\title{
Optical coherence tomography angiography - use in ophthalmological practice
}

\section{Angiografia optycznej koherentnej tomografii - zastosowanie w praktyce okulistycznej}

\author{
Bernadetta Płatkowska ${ }^{1}$, Magdalena Kal',2, Michał Biskup ${ }^{1}$ \\ ${ }^{1}$ Department of Ophthalmology, Regional Hospital, Kielce, Poland \\ Head of the Department: Michał Biskup MD \\ ${ }^{2}$ Collegium Medicum, Jan Kochanowski University, Kielce, Poland \\ Head of Collegium: Prof. Marianna Janion MD, PhD
}

Key words: optical coherence tomography angiography, choroidal neovascularisation, vascular disorders, age-related macular degeneration.

Słowa kluczowe: angiografia optycznej koherentnej tomografii, neowaskularyzacja naczyniówkowa, choroby naczyniowe, zwyrodnienie plamki żółtej związane z wiekiem.

\begin{abstract}
Optical coherence tomography angiography is currently the most advanced imaging technique used in the visualisation of the structure and vascular perfusion of the retina and choroid. The greatest advantages of the technique include its noninvasive character and the ability to analyse individual vascular layers. Despite certain shortcomings in the software, the technology is constantly developing. In clinical practice it is used to detect and compare neovascularisation in disorders such as age-related macular degeneration and central serous chorioretinopathy, as well as the foci of ischaemia associated with diabetic retinopathy, central retinal vein occlusion, and other ophthalmological vascular diseases. At present its potential is being studied as a screening test for early stages of diabetic retinopathy and for glaucoma. Due to difficulties with the interpretation of the results, it is important to improve the skills of ophthalmologists in this respect, and to raise the awareness of the potential applications of this method.
\end{abstract}

\section{Streszczenie}

Angiografia optycznej koherentnej tomografii jest najnowszą techniką obrazowania struktury oraz perfuzji naczyniowej siatkówki i naczyniówki. Do jej największych zalet należą nieinwazyjność oraz możliwość analizowania poszczególnych warstw naczyniowych. Pomimo ograniczeń oprogramowania technologia jest ciągle rozwijana i zyskuje coraz szersze zastosowanie. W praktyce klinicznej używana jest w celu wykrywania i porównywania neowaskularyzacji w takich schorzeniach, jak zwyrodnienie plamki żółtej związane z wiekiem, centralna surowicza chorioretinopatia, a także ogniska niedokrwienia towarzyszące retinopatii cukrzycowej, zakrzepowi żyły środkowej siatkówki i innym okulistycznym chorobom naczyniowym. Trwają badania nad możliwym wykorzystaniem tej metody jako przesiewowej we wczesnych stadiach chorób, takich jak retinopatia cukrzycowa i jaskra. W związku z trudnościami w interpretacji wyników istotne jest zwiększanie kompetencji lekarzy okulistów w tym zakresie i szerzenie wiedzy dotyczącej możliwego wykorzystania nowej metody.

\section{Introduction}

Optical coherence tomography angiography (OCTA angio-OCT) is a new, non-invasive imaging technique for three-dimensional visualisation of the retinal and choroidal vasculature in combination with their tissue structures, offering new and faster diagnostic options, and high precision monitoring of patients with agerelated macular degeneration (AMD) or other diseases. Optical coherence tomography (OCT) allows the visu- alisation of a cross-section of the central retina, optic nerve and vitreous body, and for nearly 30 years has been an invaluable additional test in ophthalmology. Angio-OCT has been used for the past 8 years to extend tissue structure imaging by adding blood flow detection, based on a split-spectrum amplitude-decorrelation algorithm (split-spectrum amplitude-decorrelation angiography - SSADA) [1]. The greatest advantage of the OCTA technique is the ability to detect pathological 
blood vessels in a quick, non-invasive and precise manner. If the patient co-operates then pupillary dilation is not required, the method does not involve administration of a contrast medium, it is safe for the patient and can be repeated multiple times. Performing the test is not a challenge, although interpreting the results can be problematic. Educational materials on the interpretation of OCTA images are not easily available, and the majority are in foreign languages. Co-operation between ophthalmologists, by sharing experience and dealing with diagnostic problems together, plays an important role in improving image interpretation competence.

\section{OCTA characteristics}

The OCTA mechanism is based on the split-spectrum amplitude-decorrelation algorithm, which amplifies the vascular signal, and lowers the background noise [1]. It consists of the acquisition of consecutive $B$ scans of the same tissue cross-section, which allows it to detect the movement of particles - erythrocytes. Cells that do not change their position during the test appear identical on the consecutive B-scans for a given area. Changes in reflectance in the analysed cross-section signify areas of blood flow, i.e. the movement of erythrocytes in the vascular lumen. Based on the detection of moving elements in all the analysed areas, the algorithm creates a map of blood vessels in the retina and choroid. It should be emphasised that a "lack of flow" in OCTA does not signify a complete absence of blood vessels, but only a lack of erythrocyte movement in the analysed area at a given time point.

Limitations of the OCTA method include artefacts that occur frequently and which can result in misinterpretation of the image. These are associated with the anatomy of the eye, potential pathologies, eye movement, as well as imperfections in the software. The most common types include flow projection artefacts and movement artefacts. Despite the availability of software reducing the effect of errors on the analysis quality, artefacts are still a significant obstacle in the interpretation of test results [2]. Typically, the analysed area of a retina is $3 \times 3 \mathrm{~mm}$ or $6 \times 6 \mathrm{~mm}$. Visualisation of a larger tissue fragment is associated with inferior image resolution. Wide-angle OCTA devices enable acquisition of scans measuring $12 \times 12 \mathrm{~mm}$, which can be used in the assessment of the medium retinal perimeter and, in clinical practice, of neovascularisation and areas of ischaemia, e.g. in diabetic retinopathy. Therefore, they can compete with fluorescein angiography [3]. To obtain higher resolutions while presenting the peripheral retina, advanced software can combine several small scans, creating an ultra-wide image [4].

The choroid contains ciliary arteries and veins, as well as the capillaries that connect them. Apart from the choroid, the vessels also supply the outer third of the retina, creating the deep vascular complex. The internal two-thirds of the retina is vascularised by the central retinal artery, and capillaries are found primarily in the ganglion cell layer, creating the superficial vascular complex. Numerous vertical anastomoses occur between the superficial and the deep layer. Physiological capillary-free areas are found along the arteries and in the fovea, creating a periarterial avascular zone and a foveal avascular zone (FAZ) [5]. Since 1967, when Novotny and Alvis described a method of visualising the vascular flow in the retina by photographing the ocular fundus following intravenous administration of fluorescein, contrast-enhanced angiography has become a standard method for the assessment of the retinal vascular system [6, 7]. OCTA, primarily due to its non-invasive character, offers an interesting alternative to fluorescein angiography which, despite considerable progress, remains invaluable in clinical practice. In spite of the relatively long duration of the test, its invasive character and potential complications, it is a reliable and well-established method, associated with a low ratio of artefacts. OCTA is a promising technology, in constant development and demonstrating a partial advantage over classical angiography, although these tests should not be considered as alternative but rather complementary options (Figure 1).

A two-dimensional image obtained in fluorescein angiography can demonstrate the vascular complexes simultaneously, which prevents a detailed assessment of either. A three-dimensional OCTA image enables examination of the overlapping layers in the full-thickness mode, as well as separate analyses of the superficial and deep vessels (Figure 2). It enables a more detailed presentation of microcirculation and a precise determination of the depth of vascular pathologies [8]. In fluorescein angiography, an accurate assessment of the neovascular network is impeded by leakage and retention of the contrasting medium, which obscures the vessels. OCTA allows visualisation of the morphology and the area of the neovascular membrane, and to compare its outline in the process of disease monitoring [9]. It also provides new insights into the pathogenesis of diseases involving choroidal neovascularisation (CNV). In the case of vessels with slow blood flow, visualisation of perfusion in OCTA is limited, as they may remain undetected [10].

The software detects blood flow while reducing background noise, just one of the quantitative parameters offered by the method. These include measurement of the flow area, used to compare perfusion in the neovascular membrane. A non-flow area is a parameter important in diseases involving ischaemia and the quantitative measurement of vascular density, and allows the creation of colour perfusion maps for en face images $[11,12]$. In the near future, in addition to the quantitative assessment of the blood flow, information about the flow rate will become available [13]. 


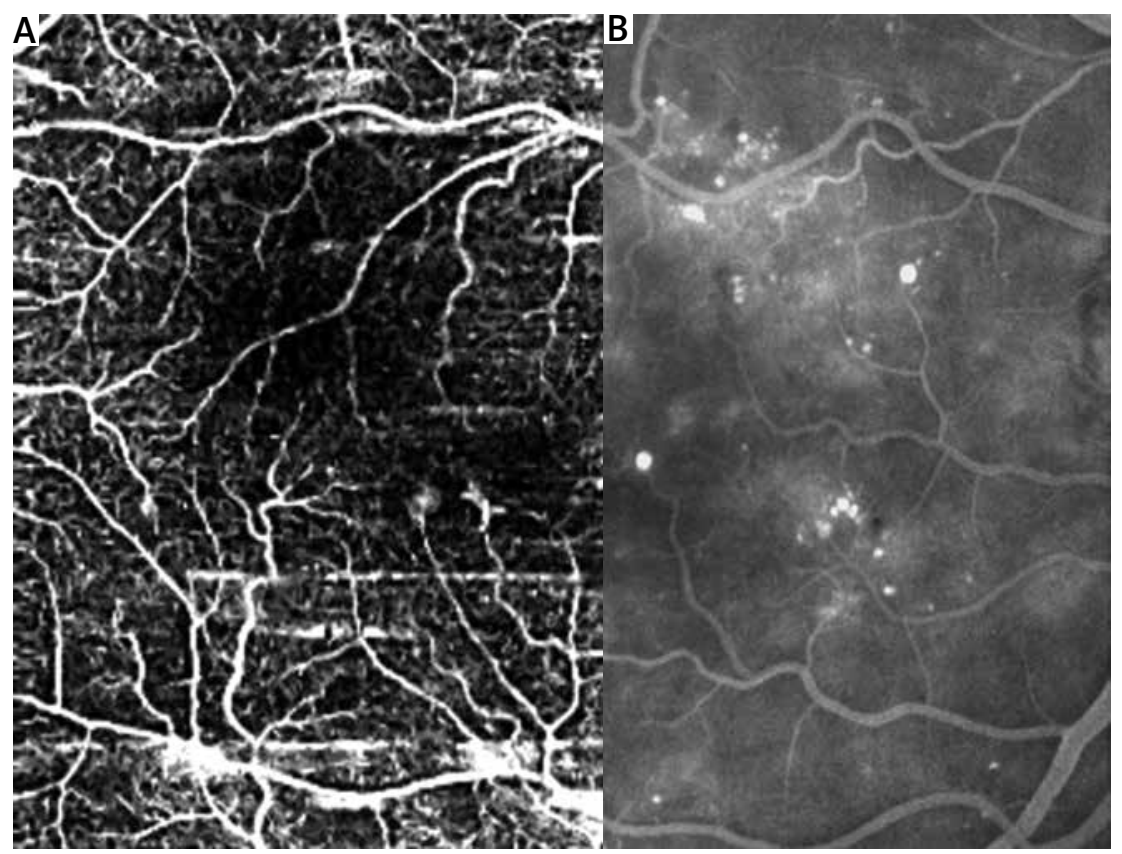

Figure 1. Image of the macula in a patient with diabetic retinopathy: A - superficial vascular complex demonstrated in OCT angiography, B - image obtained by fluorescein angiography

\section{OCTA in neovascular age-related macular degeneration}

Angiogenesis is the process of formation of new blood vessels, taking place not only in the prenatal period but also after birth, under both physiological and pathological conditions. One of the factors stimulating neovascularisation and increased vascular permeability is vascular endothelial growth factor (VEGF), whose secretion is induced by tissue hypoxia [14]. Neovascularisation takes place when the balance between the pro- and anti-angiogenic factors is disturbed in favour of the former. The neovascular membrane is a pathological structure, typically originating in the choroidal vasculature, extending through a damaged Bruch's membrane into the space below the retinal pigment epithelium (RPE) or under the neurosensory retina [5]. Histologically, two types are distinguished: the first one located below the pigment epithelium (Figures 3,4), and the second under the neurosensory layer, over Bruch's membrane - the pigment epithelium complex [15]. In certain cases, the membrane transforms into a mixed type, combining the characteristics of both forms [16]. Type 1 neovascular membranes in OCTA are seen as tangled forms, often demonstrating a pattern resembling a fan, tree or dome, like a medusa [17]. Type $2 \mathrm{CNV}$ may present as an area of hyperflow in the peripheral retina, with a glomerulus or medusa shape, surrounded by a dark halo [18].

As the macular degeneration progresses, fluid effusions, haemorrhages and fibrosis are observed in the subretinal area, and photoreceptor atrophy occurs, resulting in permanent loss of vision [5]. The gold standard in the treatment of exudative AMD consists of cyclical intravitreal injections of anti-VEGF medications, such as aflibercept and ranibizumab, which significantly slow the disease progression $[19,20]$. With the use of OCTA, reduced vascular density and blood flow in the neovascular membrane can be observed already on the first day after the intravitreal injection of aflibercept. Regression of the lesions continues over the initial 2 weeks, probably due to reduced vascular perfusion and disappearance of anastomoses. In the fourth week following the first injection, the flow in the CNV increases significantly, preceding accumulation of fluid. If a second injection is administered, the time to fluid reaccumulation extends to 6 weeks [21]. Administration of ranibizumab also significantly reduces the area and density of vessels in the neovascular membrane, which after the first injection are $40 \%$ and $50 \%$, respectively [22]. Reappearance of the neovascular membrane observed in OCTA may be the principal indicator of fluid accumulation, and visual deterioration in patients with exudative AMD [23].

A primary neovascular membrane may also be found in the retinal vessels, in the deep vascular complex, while in advanced stages it may proliferate into the choroid, which may be classified as type $3 \mathrm{CNV}$. Retinal angiomatous proliferation (RAP) may affect up to $15 \%$ of AMD patients. It is frequently bilateral, and is associated with pigment epithelial detachment (PED) and the presence of pseudodrusen; RPE disruption and geographical atrophy are often concurrent [23]. 

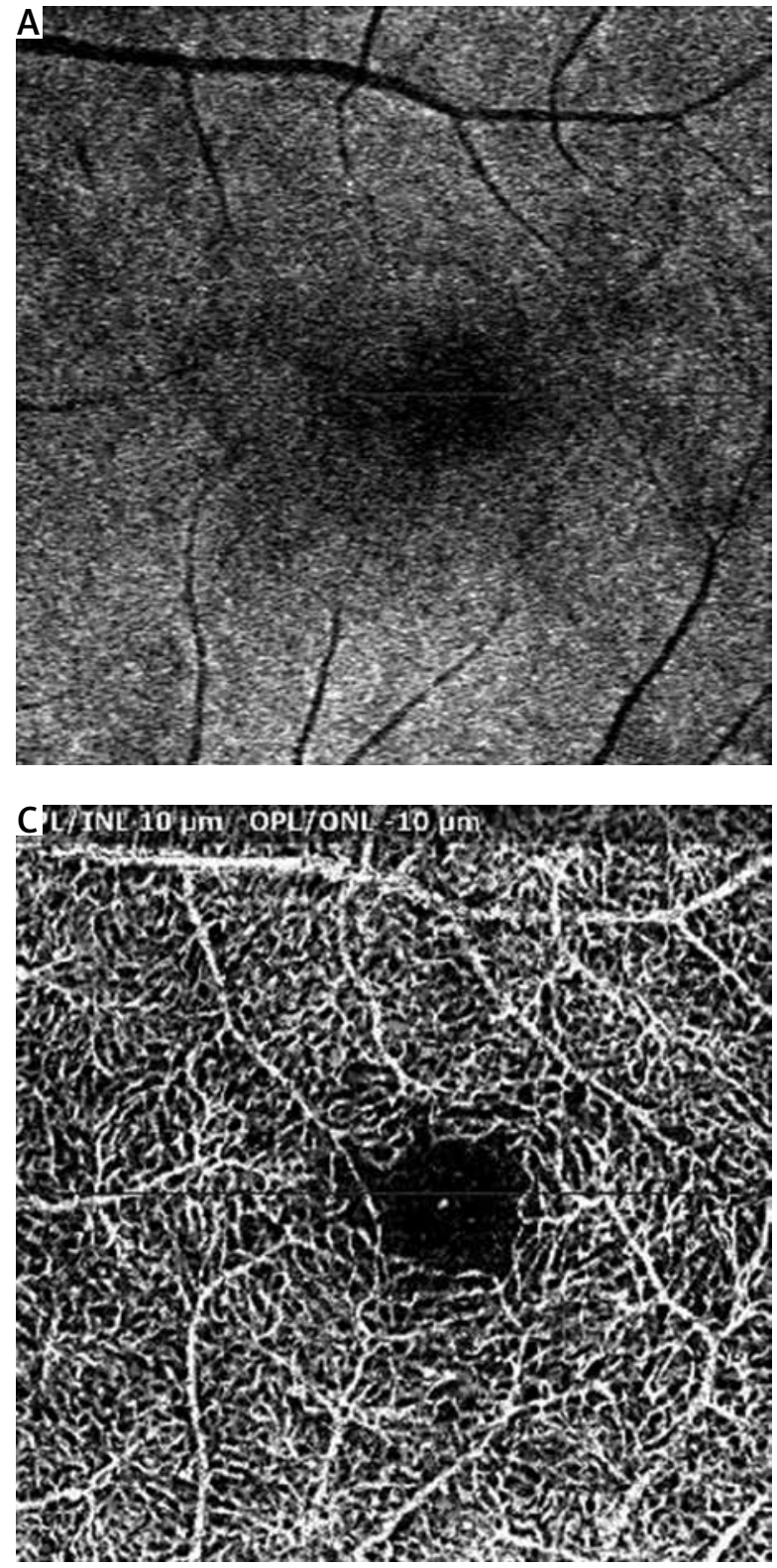

Idiopathic polypoidal choroidal vasculopathy (PCV) is considered to be another form of neovascularisation, classified as type $1 \mathrm{CNV}$ due to its frequent occurrence below the pigment epithelium [24]. It is often concurrent with AMD, but it is treated as a separate disease within the pachychoroid spectrum [25]. This disorder includes polyp-like vessel dilations, clinically presenting as orange-red intrachoroidal spherical structures. The lesions are found in the posterior pole, and predispose to recurrent atypical serous and haemorrhagic pigment epithelial detachment [26]. Typical symptoms include the rare occurrence of drusen and reduced response to anti-VEGF treatment, suggesting that PCV is a separate disorder [27].

Interestingly, the absence of fluid effusion does not always signify an absence of a neovascular mem-
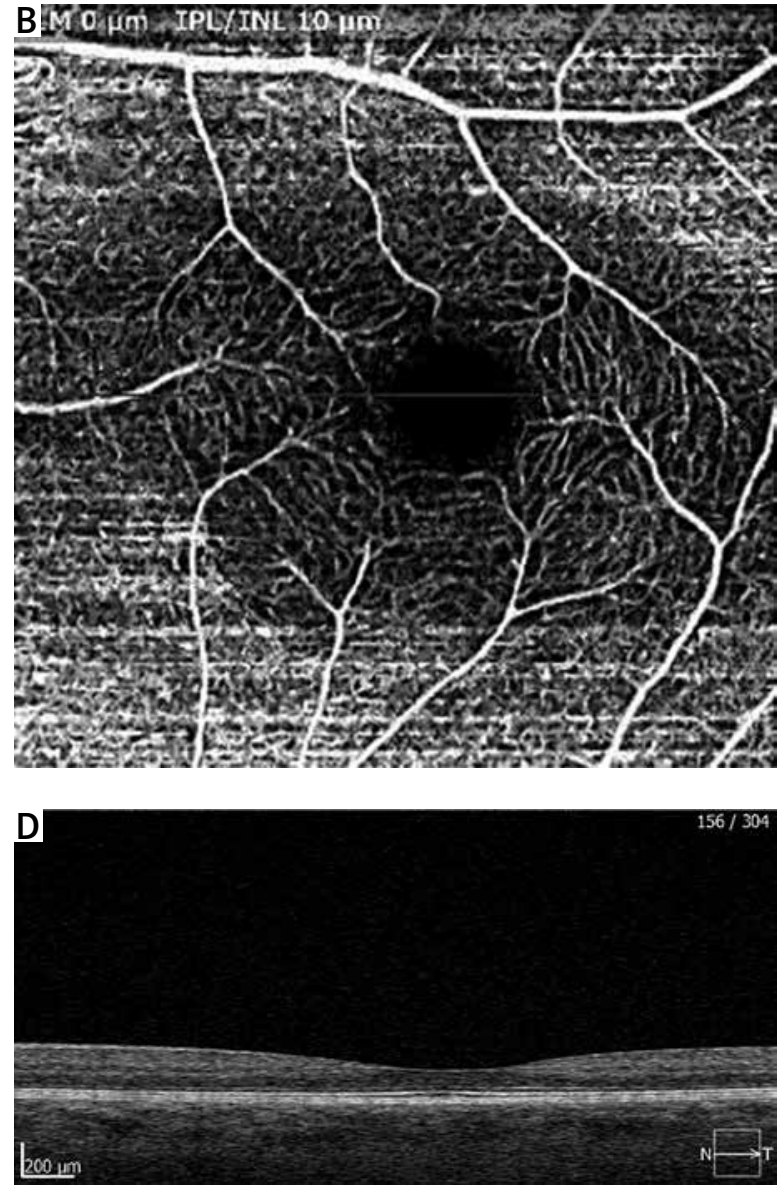

Figure 2. Examination of a healthy person: A - image of the macular area, $\mathbf{B}$ - OCTA of the superficial vascular complex, C - OCTA of the deep vascular complex, D - OCT B-scan

brane. Non-exudative CNV may be observed in the course of macular degeneration as quiescent choroidal neovascularisation, resulting in metamorphopsies and reduced retinal sensitivity, without accumulation of subretinal or intraretinal fluid in further tests [28]. Therefore, the results of angio-OCT should always be analysed together with the corresponding OCT B-scan. Absence of fluid effusion does not correspond to membrane inactivity, as this structure may change its morphology and size in the course of observation. Non-exudative CNV is often observed in one eye at the same time as exudative CNV occurs in the other eye, in which case the associated risk of exudation occurring within 2 years following the detection of the lesion is 18 times higher. No management standards have been developed for non-exudative $\mathrm{CNV}$, but 

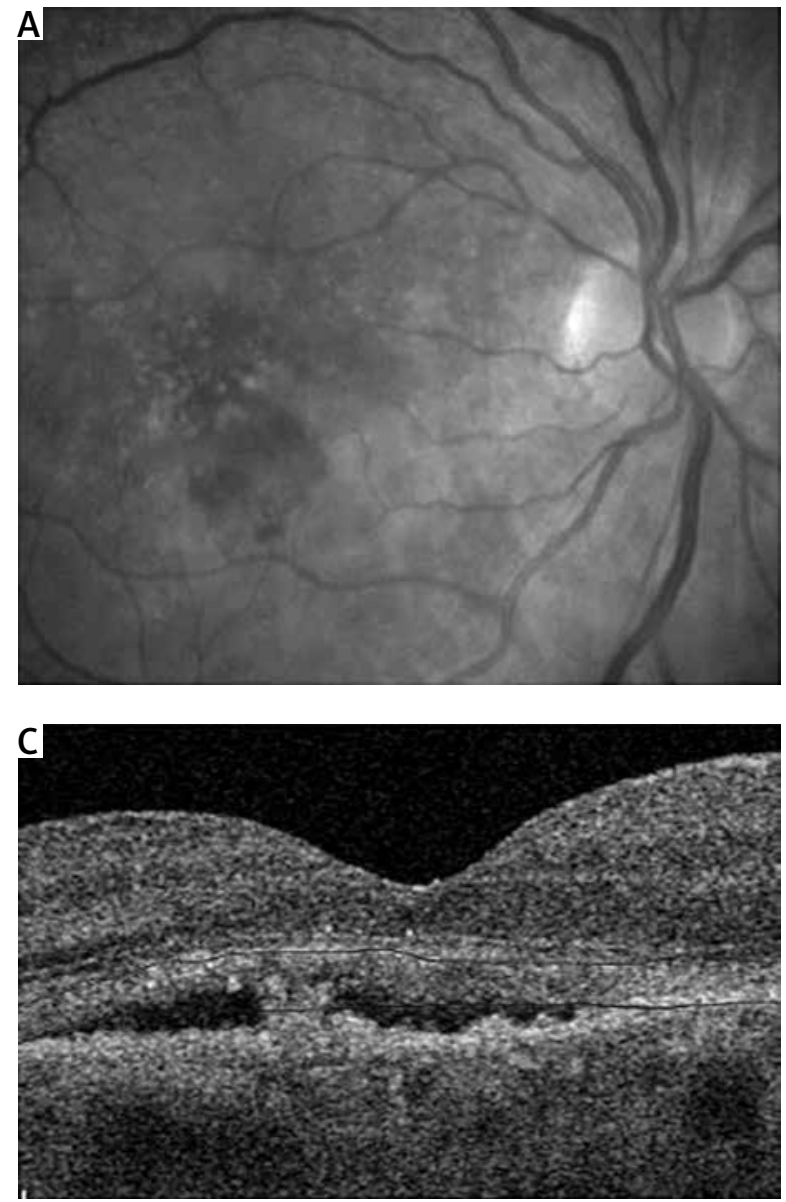

regular observations, preferably at monthly intervals, are recommended [28]. It is yet to be determined how early detection of disease conversion into the exudative form enabled by OCTA and the resulting faster implementation of treatment affect the outcomes. Future observations might lead to discovering indicators related to the highest risk of progression to the exudative form of the disease.

The previously available imaging methods usually provided intermediate information about neovascularisation: fluorescein angiography demonstrates fluid leakage, OCT demonstrates its consequence, i.e. the accumulated fluid, and OCTA shows the source of the leak, i.e. the vessels in the neovascular membrane. This allows better understanding of the pathophysiology of the disease. Angio-OCT is a useful screening tool in patients with non-exudative age-related macular degeneration, as it enables non-invasive detection of the neovascular membrane, prior to the accumulation of fluid visible in OCT. Improved detection of neovascularisation allows early intravitreal therapy to be implemented with anti-angiogenic medications, and limiting of the destruction processes affecting the tissues of the central retina. As the test can be repeated frequently, and changes in the area and flow in the

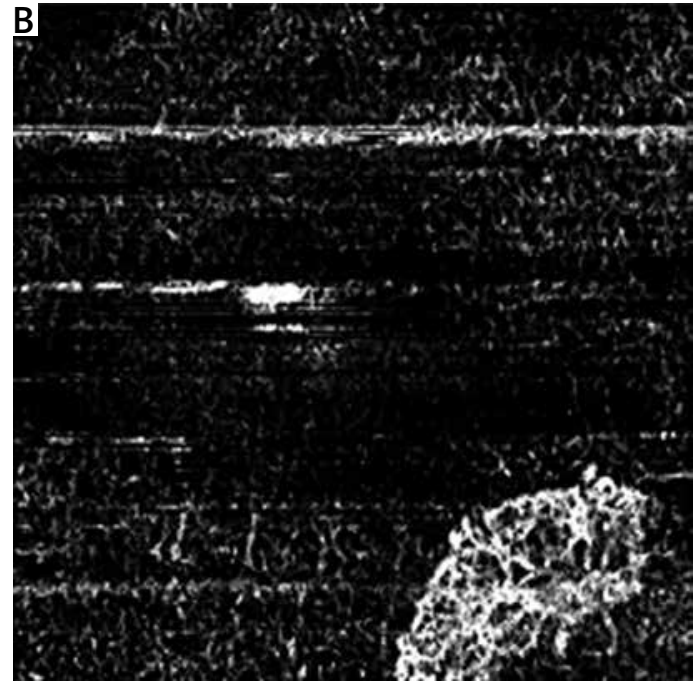

Figure 3. Type $1 \mathrm{CNV}$ : $\mathbf{A}$ - photograph of the ocular fundus, B - OCTA - dome-shaped neovascular membrane below RPE, visible pathological flow in the subretinal area, C - OCT B-scan with the analysed area marked

neovascular membrane can be compared, OCTA may also be used to monitor the effectiveness of the antiVEGF therapy, which is an important role in clinical practice (Figure 5).

\section{OCTA in diabetic retinopathy}

The complications associated with loss of vision in diabetic patients include retinopathy (non-proliferative or proliferative, depending on its severity), and diabetic macular oedema, which can be observed in any phase of retinopathy. In diabetic retinopathy, the first clinically manifested symptom is typically the presence of microaneurysms, i.e. saccular dilations in the capillary walls, visible on the scan as small, red dots. In fluorescein angiography these areas are presented as pin-point hyperfluorescence, and are usually more numerous than in the clinical examination of the analysed area. Due to its method of operation, angio-OCT detects microaneurysms only in the presence of blood flow (Figure 6) within the lesions [29].

Prior to the development of microaneurysms, eyes with diabetic retinopathy undergo changes undetectable in clinical examinations, including enlargement of the foveal avascular zone (Figure 7). OCTA allows the detection of early deviations in macular morphol- 

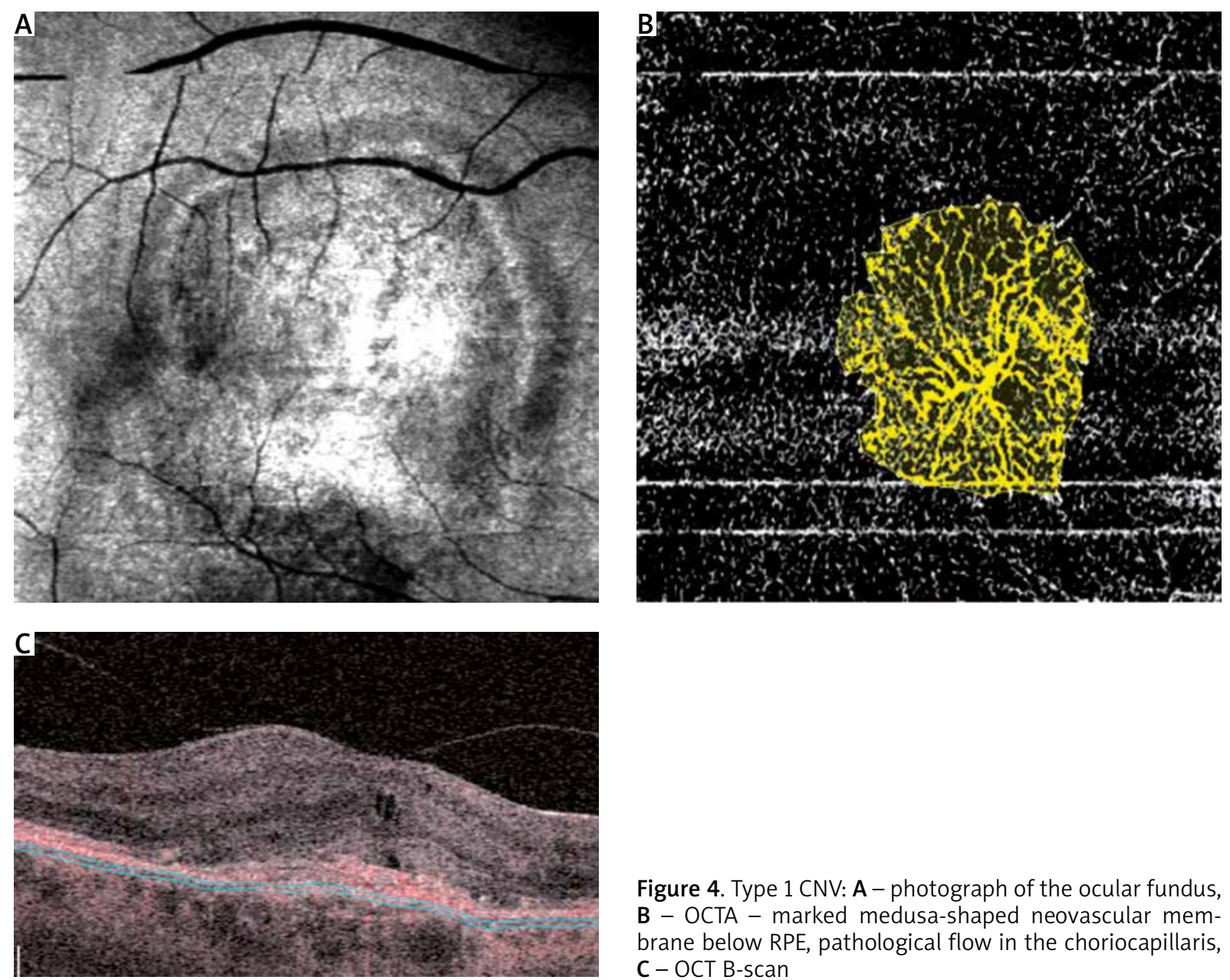

Figure 4. Type 1 CNV: A - photograph of the ocular fundus, B - OCTA - marked medusa-shaped neovascular membrane below RPE, pathological flow in the choriocapillaris, C - OCT B-scan
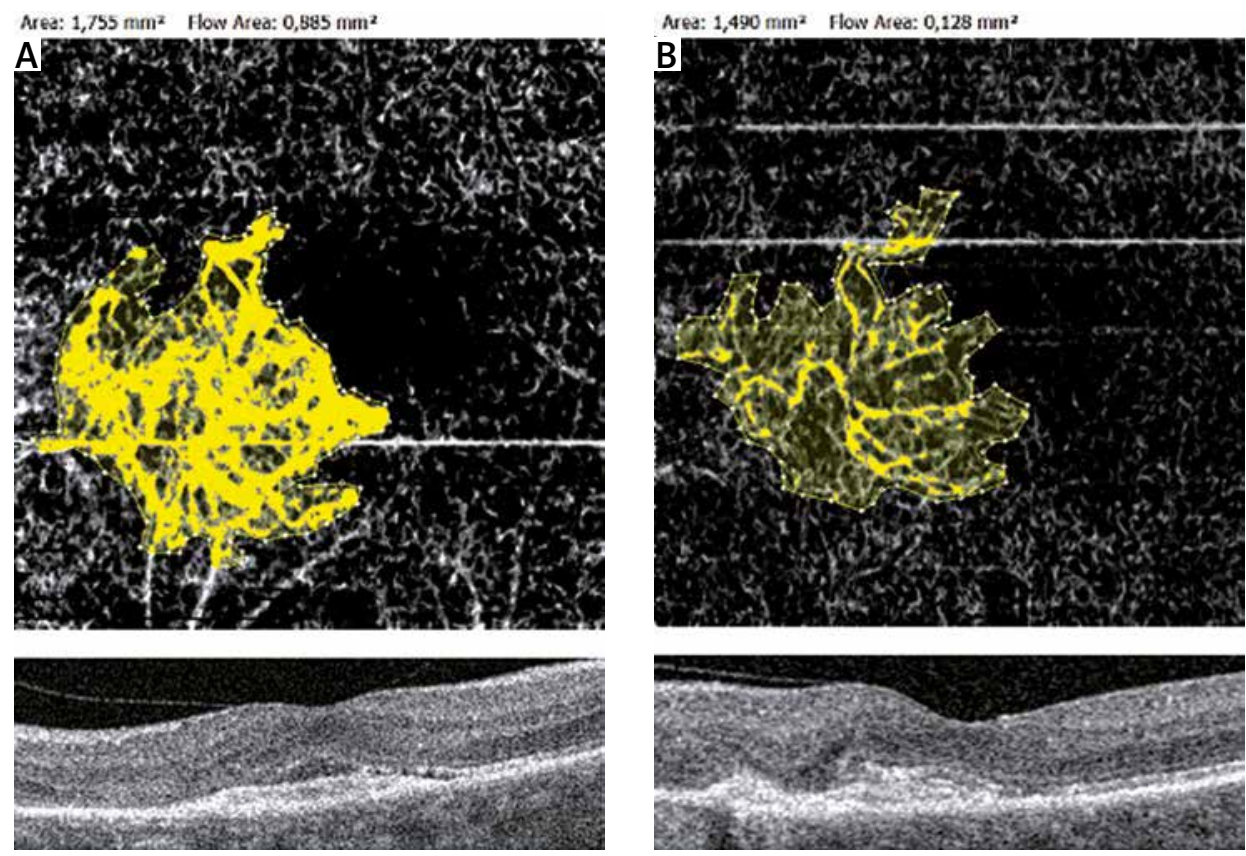

Figure 5. Comparison of the surface area of the neovascular membrane (Area) and its flow (Flow area): $\mathbf{A}$ - prior to the treatment, B - 4 weeks following the first intravitreal injection of aflibercept. A minor reduction in area and a considerable flow reduction in the neovascular membrane after treatment initiation 

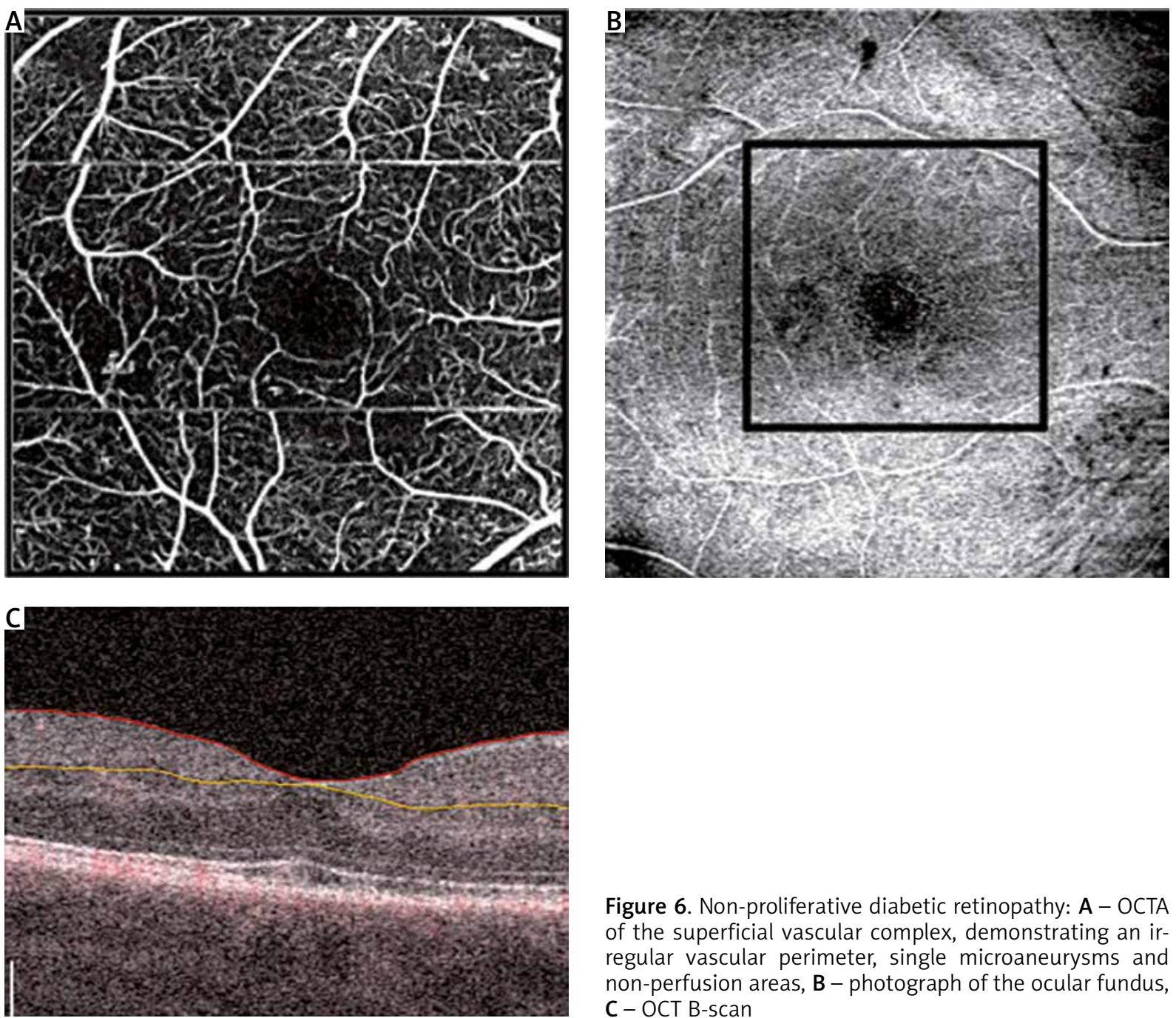

Figure 6. Non-proliferative diabetic retinopathy: A - OCTA of the superficial vascular complex, demonstrating an irregular vascular perimeter, single microaneurysms and non-perfusion areas, B - photograph of the ocular fundus, C - OCT B-scan
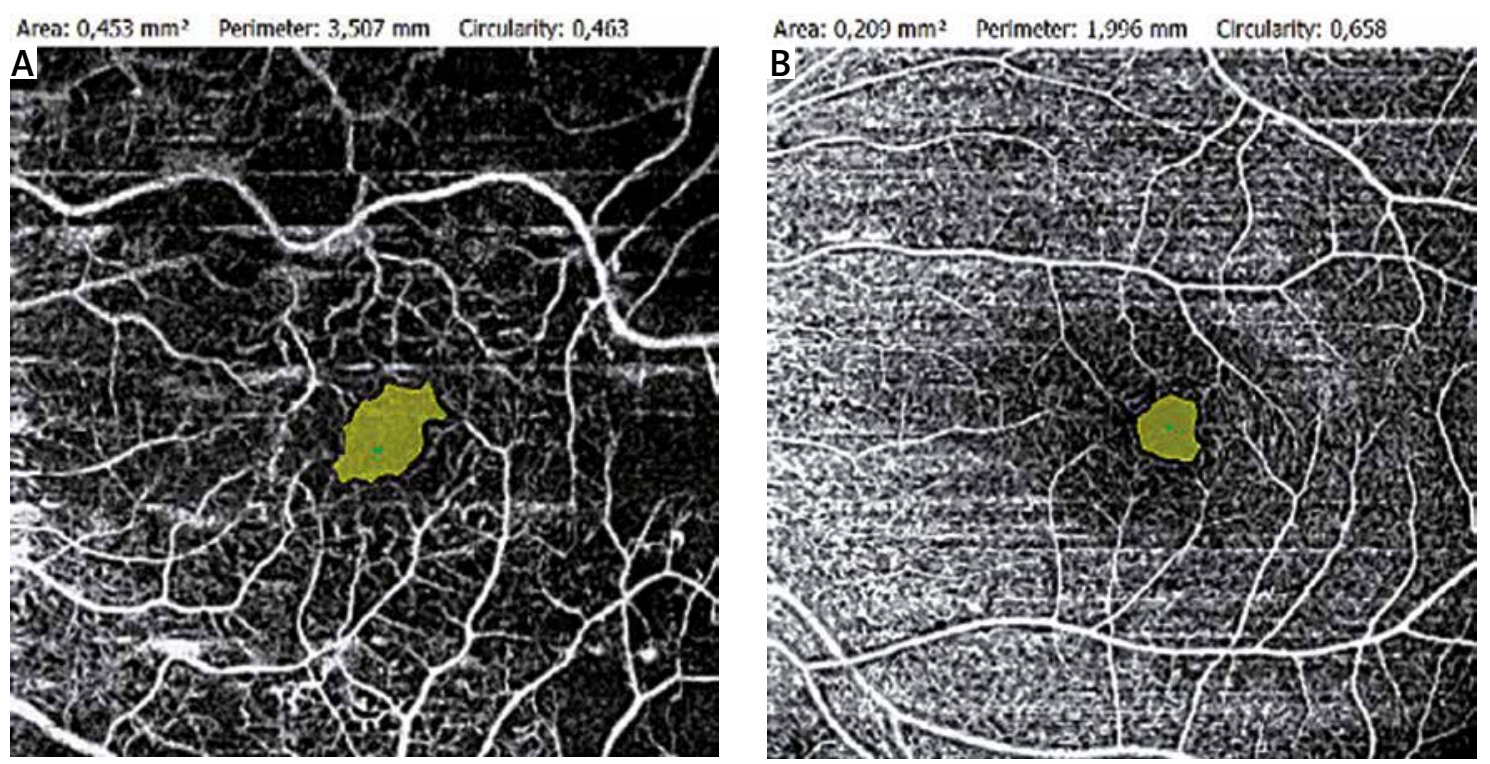

Figure 7. Comparison of the area and perimeter of FAZ in the superficial vascular complex: $\mathbf{A}$ - in an individual with diabetic retinopathy, B - in a healthy individual. Apart from the enlarged FAZ (a), an irregular capillary structure, single microaneurysms, and non-perfusion areas are visible in the patient's eye 
ogy, e.g. enlarged FAZ compared to the control group of non-diabetic patients [30]. Therefore, it can constitute an effective, non-invasive screening test in diabetic patients without clinical signs of retinopathy.

Proliferative diabetic retinopathy is a complication affecting $5-10 \%$ of patients with diabetes [5], and is associated with hypoxia-induced retinal neovascularisation. The gold standard in the treatment of proliferative retinopathy is panretinal photocoagulation laser, which consists of focal tissue coagulation to reduce oxygen demand in the tissue, thus improving internal retinal oxygenation and inhibiting the progression of microcirculatory lesions. In uncertain cases, fluorescein angiography is used as an auxiliary test, as it can demonstrate an increasing, irregular hyperfluorescence corresponding to the leakage of dye from the neovascular tissue. It also presents irregular, hypofluorescent areas of retinal ischaemia, indicating the need for laser therapy.

Angio-OCT demonstrates vascular non-perfusion areas in the deep and superficial vascular complex separately, which allows assessment of lesion progression in the course of diabetic retinopathy. OCTA offers greater precision in the evaluation of vascular non-perfusion compared to fluorescein angiography [29]. Due to constant technological development, the analysable area is increasing, making the assessment of the peripheral retina, important in diabetic retinopathy, possible.

\section{OCTA in central serous chorioretinopathy}

The pachychoroid phenotype includes various disorders characterised by specific lesions in the choroidal vessels, RPE dysfunction, and focal or diffuse choroidal thickening. Pachychoroid spectrum diseases include central serous chorioretinopathy (CSC), and the mentioned polypoidal choroidal vasculopathy [31].

CSC is a disease with a varied, and not fully understood pathomechanism. It usually manifests as a monolateral visual impairment in the form of blurred vision, metamorphopsia or micropsia [5]. The diagnosis is based on the demonstration of retinal detachment in the posterior pole due to fluid effusion during a stereoscopic examination using a slit lamp. An OCT scan demonstrates serous detachment of the sensory retina in the macular area due to fluid effusion between the pigment epithelium and neurosensory retina, probably resulting from increased permeability of choriocapillaries [32]. In most cases CSC resolves spontaneously, and the course of the disease can be monitored by assessing the amount of fluid using OCT. Usually the "watchful waiting" method is applied. Treatments with proven effectiveness include focal retinal laser therapy at the site of the leak, photodynamic therapy in chronic CSC and use of mineralocorticoid inhibitors [5].
In a few percent of patient with CSC, subretinal neovascularisation occurs, significantly worsening the prognosis [33]. When CNV is suspected, contrastenhanced angiography is conducted, and in confirmed cases anti-angiogenic therapy is considered. OCTA demonstrates a similar sensitivity and specificity in detection of neovascular membranes in eyes with chronic CSC to fluorescein angiography, and in some patients it is superior in diagnosing $\mathrm{CNV}$ not observable by fluorescein angiography, indocyanine green angiography or OCT $[34,35]$. It has been observed that neovascularisation in CSC correlates with a slight RPE detachment having small undulations in OCT B-scans [35]. Although contrast-enhanced tests remain the gold standard in the diagnosis of $\mathrm{CNV}$, and the analyses above were based on a small patient pool, OCT angiography, due to its non-invasive character, should be considered as a first-line test when neovascularisation is suspected in eyes with chronic CSC $[34,36]$.

\section{OCTA in primary open angle glaucoma}

Primary open angle glaucoma (POAG) is a multifactorial disease, whose pathogenesis is not fully understood. Along with the progressing neuropathy, deficits in the field of vision occur, resulting in irreversible loss of vision. Increased intraocular pressure is an important factor affecting the disease progression; however, in some glaucoma patients intraocular pressure is normal [5].

Local and general systemic vascular lesions, which appear to be strictly correlated, play an important role in the pathomechanism of glaucomatous neuropathy [37]. OCTA provides a precise and repeatable assessment of the vascular flow on the optic disc, as well as in the peripapillary and macular area in healthy individuals (Figure 8) and glaucoma patients. Naturally, perfusion in these areas is visibly reduced in patients with POAG, which may be determined quantitatively and compared in subsequent tests with the use of OCTA and the SSADA algorithm by computation of the flow index and vessel density [38-40].

It has been demonstrated that reduction in the disc flow index and vessel density in this area correlates closely with the thickness of the ganglion cell layer, which may be useful in monitoring disease progression [41]. Another parameter, known as peripapillary vessel density, correlates significantly with deficits in the field of vision in patients with moderately advanced and advanced glaucoma [42].

Perfusion of the optic disc in OCTA is significantly reduced in patients at an early disease phase, with the disc flow index reduced by $35 \%$ and vascular area by $34 \%$ in the group of patients with preperimetric glaucoma compared to healthy individuals, which is clinically important as it may help to determine the 

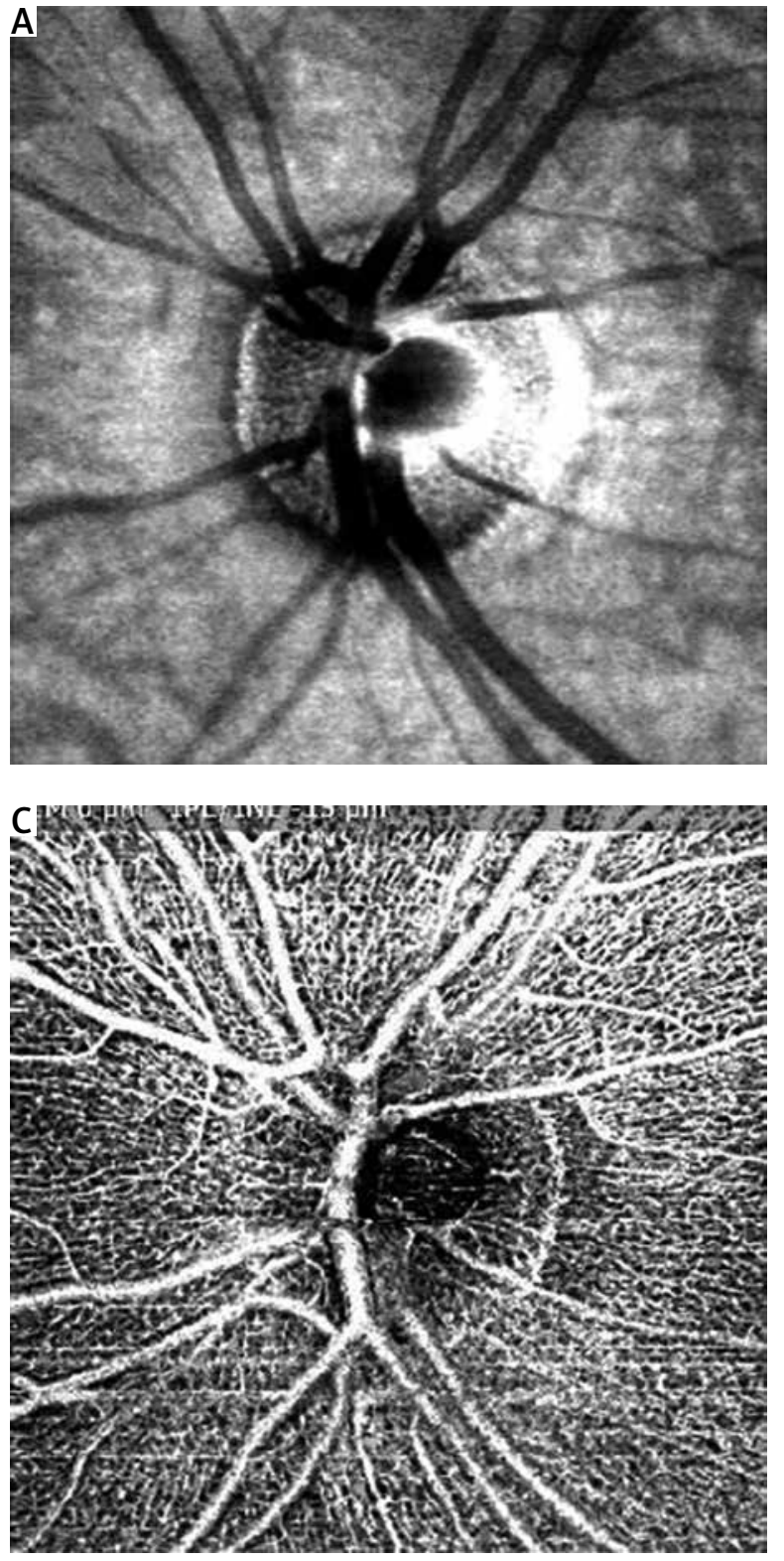

criteria for introducing anti-glaucoma treatment in patients with suspected glaucoma [43].

Further research on the use of the quantitative parameters offered by OCTA can contribute to the potential uses of the technique in the diagnostics, staging and monitoring of POAG patients [40].

\section{Conclusions}

OCTA is becoming an important element in the diagnostics of ophthalmological disorders, due to its increasing application range and potential for improving our understanding of the pathophysiology of posterior segment disorders. It is important to conduct more studies using the new method, and to raise
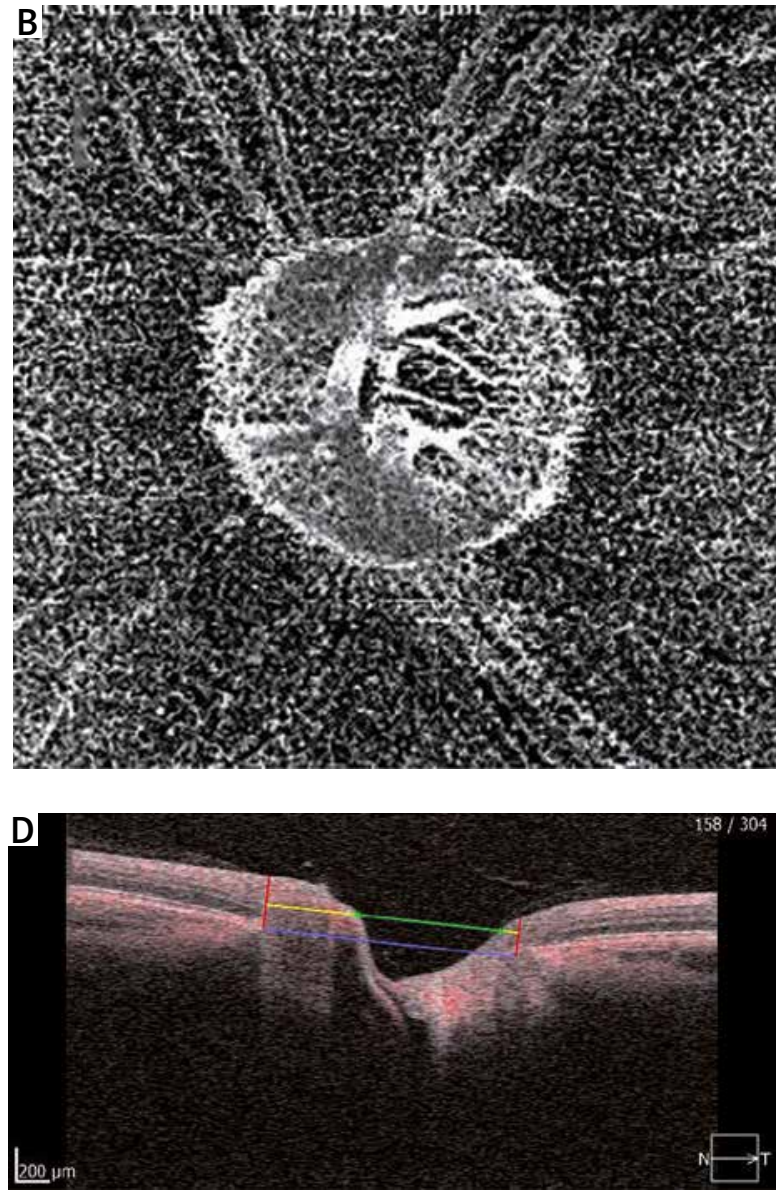

Figure 8. Optic disc test in a healthy individual: $\mathbf{A}$ - photograph en face, B - OCTA of the deep vascular complex, C-OCTA of the superficial vascular complex, D - OCT B-scan

the awareness of its potential applications. The continuing improvement in OCT angiography suggests good prospects for its increasing role in daily ophthalmological practice.

\section{Acknowledgments}

Project financed under the programme of the Minister of Science and Higher Education called "Regional Initiative of Excellence" in the years 20192022, project no. 024/RID/2018/19, amount of financing $11999000.00 \mathrm{zl}$.

\section{Conflict of interest}

The authors declare no conflict of interest. 


\section{References}

1. Jia Y, Tan O, Tokayer J, Potsaid B, Wang Y, Liu JJ, Kraus MF Subhash H, Fujimoto JG, Hornegger J, Huang D. Split-spectrum amplitude-decorrelation angiography with optical coherence tomography. Opt Express 2012; 20: 4710-4725.

2. Spaide RF, Fujimoto JG, Waheed NK. Image artifacts in optical coherence tomography angiography. Retina 2015; 35: 2163-2180.

3. Sawada O, Ichiyama Y, Obata S, Ito Y, Kakinoki M, Sawada T, Saishin Y, Ohji M. Comparison between wide-angle OCT angiography and ultra-wide field fluorescein angiography for detecting non-perfusion areas and retinal neovascularization in eyes with diabetic retinopathy. Graefes Arch Clin Exp Ophthalmol 2018; 256: 1275-1280.

4. Zhang Q, Rezaei KA, Saraf SS, Chu Z, Wang F, Wang RK. Ultra-wide optical coherence tomography angiography in diabetic retinopathy. Quant Imaging Med Surg 2018; 8: 743-753.

5. Kański JJ, Bowling B. Okulistyka kliniczna. Elsevier Urban \& Partner, Wrocław 2017.

6. Novotny HR, Alvis DL. A method of photographing fluorescence in circulating blood in the human retina. Circulation 1961; 24: 82-86.

7. De Barros Garcia JMB, Isaac DLC, Avila M. Diabetic retinopathy and OCT angiography: clinical findings and future perspectives. Int J Retina Vitreous 2017; 3: 14.

8. Spaide RF, Klancnik JM, Cooney MJ. Retinal vascular layers imaged by fluorescein angiography and optical coherence tomography angiography. JAMA Ophthalmol 2015; 133: 45-50.

9. Jia Y, Bailey ST, Wilson DJ, Tan O, Klein ML, Flaxel CJ, Potsaid B, Liu JJ, Lu CD, Kraus MF, Fujimoto JG, Huang D. Quantitative optical coherence tomography angiography of choroidal neovascularization in age-related macular degeneration. Ophthalmology 2014; 121: 1435-1444.

10. Schachat AP, Wilkinson CP, Hinton DR, Wiedemann P, Freund KB, Sarraf D. Ryan's Retina E-Book. Elsevier Health Sciences 2017.

11. Hwang TS, Gao SS, Liu L, et al. Automated quantification of capillary nonperfusion using optical coherence tomography angiography in diabetic retinopathy. JAMA Ophthalmol 2016; 134: 367-373

12. Al-Sheikh M, Tepelus TC, Nazikyan T, Sadda SR. Repeatability of automated vessel density measurements using optical coherence tomography angiography. Br J Ophthalmol 2017; 101: 449-452.

13. Ploner SB, Moult EM, Choi W, Waheed NK, Lee BK, Novais EA, Cole ED, Potsaid B, Husvogt L, Schottenhamml J, Maier A, Rosenfeld PJ, Duker JS, Hornegger J, Fujimoto JG. Toward quantitative optical coherence tomography angiography: visualizing blood flow speeds in ocular pathology using variable interscan time analysis. Retina 2016; 36 Suppl 1: 118-126.

14. Krock BL, Skuli N, Simon MC. Hypoxia-induced angiogenesis: good and evil. Genes Cancer 2011; 2: 1117-1133.

15. Gass J, Donald M. Biomicroscopic and histopathologic considerations regarding the feasibility of surgical excision of subfoveal neovascular membranes. Am J Ophthalmol 1994; 118: 285-298.

16. Coscas G. Optical Coherence Tomography in Age-Related Macular Degeneration. Springer-Verlag, Berlin Heidelberg 2009.
17. Kuehlewein L, Bansal M, Lenis TL, Iafe NA, Sadda SR, Bonini Filho MA, De Carlo TE, Waheed NK, Duker JS, Sarraf D. Optical coherence tomography angiography of type 1 neovascularization in age-related macular degeneration. Am J Ophthalmol 2015; 160: 739-748.

18. El Ameen A, Cohen SY, Semoun O, Miere A, Srour M, Quaranta-El Maftouhi M, Oubraham H, Blanco-Garavito R, Querques G, Souied EH. Type 2 neovascularization secondary to age-related macular degeneration imaged by optical coherence tomography angiography. Retina 2015; 35: 2212-2218.

19. Ferrara N, Damico L, Shams N, Lowman H, Kim R. Development of ranibizumab, an anti-vascular endothelial growth factor antigen binding fragment, as therapy for neovascular age-related macular degeneration. Retina 2006; 26: 859-870.

20. Heier JS, Brown DM, Chong V, Korobelnik JF, Kaiser PK, Nguyen OD, Kirchhof B, Ho A, Ogura Y, Yancopoulos GD, Stahl N, Vitti R, Berliner AJ, Soo Y, Anderesi M, Groetzbach G, Sommerauer B, Sandbrink R, Simader C, Schmidt-Erfurth U. Intravitreal aflibercept (VEGF Trap-Eye) in wet age-related macular degeneration. Ophthalmology 2012; 119: 2537-2548.

21. Huang D, Jia Y, Rispoli M, Tan O, Lumbroso B. Optical coherence tomography angiography of time course of choridal neovascularization in response to anti-angiogenic treatment. Retina 2015; 35: 2260-2264.

22. Kuehlewein L, Sadda SR, Sarraf D. OCT angiography and sequential quantitative analysis of type 2 neovascularization after ranibizumab therapy. Eye 2015; 29: 932-935.

23. Tsai ASH, Cheung N, Gan ATL, Jaffe GJ, Sivaprasad S, Wong TY, Cheung CMG. Retinal angiomatous proliferation. Surv Ophthalmol 2017; 62: 462-492.

24. Alshahrani ST, Al Shamsi HN, Kahtani ES, Ghazi NG. Spectral-domain optical coherence tomography findings in polypoidal choroidal vasculopathy suggest a type 1 neovascular growth pattern. Clin Ophthalmol 2014; 8: 1689-1695.

25. Yannuzzi LA, Sorenson J, Spaide RF, Lipson B. Idiopatic polypoidal choroidal vasculopathy (IPCV). Retina 2012; 32 Suppl 1: 1-8.

26. Querques G, Srour M, Massamba N, Georges A, Ben Moussa N, Rafaeli O, Souied EH. Functional characterization and multimodal imaging of treatment-naïve "quiescent" choroidal neovascularization. Invest Ophthalmol Vis Sci 2013; 54: 6886-6892.

27. Teo KYC, Gillies M, Fraser-Bell S. The use of vascular endothelial growth factor inhibitors and complementary treatment options in polypoidal choroidal vasculopathy: a subtype of neovascular age-related macular degeneration. Int J Mol Sci 2018; 19: 2611.

28. Bailey ST, Thaware O, Wang J, Hagag AM, Zhang X, Flaxel CJ, Lauer AK, Hwang TS, Lin P, Huang D, Jia Y. Detection of nonexudative choroidal neovascularization and progression to exudative choroidal neovascularization using OCT angiography. Ophthalmol Retina 2019; 3: 629-636.

29. Couturier A, Mané V, Bonnin S, Erginay A, Massin P, Gaudric A, Tadayoni R. Capillary plexus anomalies in diabetic retinopathy on optical coherence tomography angiography. Retina 2015; 35: 2384-2391.

30. Takase N, Nozaki M, Kato A, Ozeki H, Yoshida M, Ogura Y. Enlargement of foveal avascular zone in diabetic eyes evaluated by en face optical coherence tomography angiography. Retina 2015; 35: 2377-2383. 
31. Kumawat D, Bhayana A, Kumar V. Pachychoroid spectrum disorders: a review of clinical features and management. DJO 2019; 30: 7-15.

32. Gass JD. Specific diseases causing disciform macular detachment. Stereoscopic Atlas of Macular Diseases 1997; 1: 52-70.

33. Loo RH, Scott IU, Flynn HW Jr, Gass JD, Murray TG, Lewis ML, Rosenfeld PJ, Smiddy WE. Factors associated with reduced visual acuity during long-term follow-up of patients with idiopathic central serous chorioretinopathy. Retina 2002; 22: 19-24.

34. Bonini Filho MA, de Carlo TE, Ferrara D, Adhi M, Baumal CR, Witkin AJ, Reichel E, Duker JS, Waheed NK. Association of choroidal neovascularization and central serous chorioretinopathy with optical coherence tomography angiography. JAMA Ophthalmol 2015; 133: 899-906.

35. Quaranta-El Maftouhi M, El Maftouhi A, Eandi CM. Chronic central serous chorioretinopathy imaged by optical coherence tomographic angiography. Am J Ophthalmol 2015; 160: 581-587.

36. Do DV. Detection of new-onset choroidal neovascularisation. Curr Opin Ophthalmol 2013; 24: 244-247.

37. Choi J, Kook MS. Systemic and ocular hemodynamic risk factors in glaucoma. Biomed Res Int 2015; 2015: 141905.

38. Xu H, Yu J, Kong X, Sun X, Jiang C. Macular microvasculature alterations in patients with primary open-angle glaucoma: a cross-sectional study. Medicine 2016; 95: 4341.

39. Jia Y, Wei E, Wang X, Zhang X, Morrison JC, Parikh M, Lombardi LH, Gattey DM, Armour RL, Edmunds B, Kraus MF, Fujimoto JG, Huang D. Optical coherence tomography angiography of optic disc perfusion in glaucoma. Ophthalmology 2014; 121: 1322-1332.

40. Liu L, Jia Y, Takusagawa HL, Pechauer AD, Edmunds B, Lombardi L, Davis E, Morrison JC, Huang D. Optical coherence tomography angiography of the peripapillary retina in glaucoma. JAMA Ophthalmol 2015; 133: 1045-1052.

41. Wang X, Jiang C, Ko T, Kong X, Yu X, Min W, Shi G, Sun X. Correlation between optic disc perfusion and glaucomatous severity in patients with open-angle glaucoma: an optical coherence tomography angiography study. Graefes Arch Clin Exp Ophthalmol 2015; 253: 1557-1564.

42. Shin JW, Lee J, Kwon J, Choi J, Kook MS. Regional vascular density - visual field sensitivity relationship in glaucoma according to disease severity. Br J Ophthalmol 2017; 101: 1666-1672.

43. Jia Y, Morrison JC, Tokayer J, Tan O, Lombardi L, Baumann B, Lu CD, Choi W, Fujimoto JG, Huang D. Quantitative OCT angiography of optic nerve head blood flow. Biomed Opt Express 2012; 3: 3127-3137.

\section{Address for correspondence:}

\section{Bernadetta Płatkowska}

Department of Ophthalmology

Regional Hospital

Kielce, Poland

Phone: +48662087130

E-mail: bernadetta.platkowska@gmail.com 